\title{
(息)
}

Citation:

Fijalkowski, AA (2016) Truth and Reconciliation Commissions. In: An Introduction to Transitional Justice. Routledge, pp. 91-112. ISBN 1138943223, 9781138943223

Link to Leeds Beckett Repository record:

https://eprints.leedsbeckett.ac.uk/id/eprint/6106/

Document Version:

Book Section (Accepted Version)

This is an Accepted Manuscript of a book chapter published by Routledge in An Introduction to Transitional Justice on 21 Nov 2016, available online: http://www.routledge.com/9781138943223

The aim of the Leeds Beckett Repository is to provide open access to our research, as required by funder policies and permitted by publishers and copyright law.

The Leeds Beckett repository holds a wide range of publications, each of which has been checked for copyright and the relevant embargo period has been applied by the Research Services team.

We operate on a standard take-down policy. If you are the author or publisher of an output and you would like it removed from the repository, please contact us and we will investigate on a case-by-case basis.

Each thesis in the repository has been cleared where necessary by the author for third party copyright. If you would like a thesis to be removed from the repository or believe there is an issue with copyright, please contact us on openaccess@leedsbeckett.ac.uk and we will investigate on a case-by-case basis. 


\section{Truth and Reconciliation Commissions}

\section{Agata Fijalkowski}

'Do you want to remember, or to forget?'1

\section{Definition and key components (truth/reconciliation/commission)}

How can we define a truth and reconciliation commission? The three main elements of truth, reconciliation and commission carry broad responsibilities and expectations. In her study on truth commissions, Hayner notes:

A truth commission (1) is focused on the past, rather than ongoing events; (2) investigates a pattern of events that took place over a period of time; (3) engages directly and broadly with the affected population, gathering information on their experiences; (4) is a temporary body, with the aim of concluding a final report; and (5) is officially authorised or empowered by the state under review. ${ }^{2}$

As we shall see, as Hayner rightly suggests, it is vital not to define truth and reconciliations commissions too narrowly. It is also immediately apparent that a commission is distinct from a governmental human rights body or from a judicial commission of inquiry. In fact, truth commissions have been created under many names. A brief historical overview is needed before going on to the purpose of these bodies. A better understanding of the key components will arise when a closer look is taken at the criteria needed for a commission's actual operation. This chapter will focus on key questions concerning their work and refer to important examples throughout the discussion.

\section{Brief historical overview}

The first truth commission was established in Argentina in 1981. It was known as the

\footnotetext{
${ }^{1}$ Priscilla B. Hayner, Unspeakable Truths: Transitional Justice and the Challenge of Truth Commissions (Routledge, $2^{\text {nd }}$ ed, 2011) 1.

${ }^{2}$ Ibid, 11-12.
} 
National Commission on the Disappeared (CONADEP). The term, 'truth commission', would emerge later. CONADEP was created in response to the individuals who disappeared following an intense and brutal government campaign against subversives. When the military forces seized power in 1976, the communists became the main targets for elimination, resulting in some 10,000 to 30,000 people arrested, tortured, and killed. The bodies were disposed of with the purpose of never being found. As a result, families were in anguish at not knowing the fate of the victims. Before acquiescing to popular elections (as discussed in the chapter on 'Amnesty') and a return to civilian rule, the military granted themselves immunity from prosecution and also promulgated a decree ordering the destruction of all documents concerning this violent government campaign of disappearance.

CONADEP was created under Raúl Alfonsín’s presidency (1983-1989). President Alfosín carefully selected the ten members of the commission, which was, after an initial resistance, assisted by non-governmental organisations (NGOs). CONADEP would receive no cooperation from the Argentine armed forces. In terms of its operation, the Commission held no public hearings. The Commission's profile, however, was very public, in the sense that the Commission's existence and function were known to most people and were widely discussed in the social media. CONADEP collected 7,000 statements over a nine-month period, and documented 8,960 individuals who had disappeared. Importantly, among those interviewed were 1,500 persons who could provide details about the conditions of detention and methods of torture, which aided the commission in identifying the detention centres. Some 365 torture centres were uncovered. ${ }^{3}$

When the commission released a full report, Nunca Más (Never Again), to the president, it was a top seller and a publication that was in demand. ${ }^{4}$ Parts of the report contained critical information that was presented to the prosecution, which was key to the

\footnotetext{
${ }^{3}$ Ibid, 46.

${ }^{4}$ Nunca Más, Report of the Argentine Commission on the Disappeared (Farrar, Straus \& Giroux, 1986) and Emilio Crenzel, 'Argentina's National Commission on the Disappearance of Persons: Contributions to Transitional Justice' (2008) 2 International Journal of Transitional Justice 173-191.
} 
trial of several of the military juntas - indeed, five were successfully charged and imprisoned. However, the prosecution's momentum was short-lived; even those convicted were pardoned by incoming president Carlos Menem. ${ }^{5}$ In 1995 information was provided by one of the key perpetrators involved in death flights, where detainees were drugged and dropped from airplanes into the sea. Also that year, the commander-in-chief of the army publicly acknowledged the crimes of the Dirty War. In 1998, criminal trials began for cases of kidnapping (these were excluded from amnesty). ${ }^{6}$ In 1999 full investigations were carried out to identify, publicly, individuals responsible, before applying for amnesty. In 2001 the highest court held the amnesty provisions unconstitutional. In 2003, the Argentine parliament, supported by political will, overturned the amnesties with retroactive effect. By 2009 1,400 individuals were charged for crimes of the Dirty $\mathrm{War}^{7}$ and 68 per cent were convicted by 2011. ${ }^{8}$ Thus, it can be said that Argentina arguably paved the way for such commissions.

The next important example is Chile. Here we see 'truth commission' appear as part of the name of the body itself: National Commission on Truth and Reconciliation. The military coup in Chile in September 1973 characterised 17 years of dictatorial rule under General Augusto Pinochet. During this time, independent organisations challenged almost every case of illegal detention or disappearance in court. The national courts rarely supported claims against the regime's actions. Yet the work of the independent organisations was invaluable, as they kept clear records of the individuals detained or disappeared. Despite the repressive rule it is important to note that Pinochet was a popular figure in a conservative, right wing Chilean society. The changes Pinochet made before civilian rule took over are discussed in the chapter on 'Amnesty'. These changes constrained the leadership of civilian rule. Yet President Patricio Aylwin (1990-1994) set up a National Truth and Reconciliation Commission that comprised eight members, four of whom were supporters of Pinochet. The

\footnotetext{
${ }^{5}$ Priscilla B. Hayner, above n 1, 46.

${ }^{6}$ Ibid, 47.

${ }^{7}$ Dirty War refers to the campaign by the Argentine government against suspected dissidents and subversives.

${ }^{8}$ Priscilla B. Hayner, above n 1, 47.
} 
Commission's mandate was to investigate 'disappearances after arrest, executions, torture leading to death committed by government or people in their service, as well as kidnappings and attempts on the life of persons carried out by private citizens for political reasons' ${ }^{9}{ }^{9}$ The mandate, however, did not include cases of torture that did not result in death. The practices of torture were described in some detail in the Commission's report but only after the setup of a second commission in 2003 was there a specific focus on torture survivors.

The 1990 Commission only had nine months to conclude its findings. During that time the Commission was able to conduct more thorough investigations of its small number of cases, using the invaluable work of independent organisations. It was focused on developing as complete picture as possible as to the violations of human rights that occurred. It had no power to subpoena and it received little cooperation from the armed forces. When the report was released in 1991, its 1,800 pages provided a powerful indictment against the Pinochet regime. The report confirmed that 95 per cent of the violations were ascribed to state agents and four per cent to leftist groups. In the aftermath of its release, President Aylwin asked for forgiveness from the victims and emphasised the need for forgiveness and reconciliation, asking the armed forces to recognise the victims' plight. In response, Pinochet responded with a detailed expression of disagreement with the Commission's report. The report was not as widely publicised as the Argentinian one. Any discussions about reconciliation petered out. It was not until Pinochet's arrest in London in 1998 that the issue of past human rights violations could be discussed openly and widely. ${ }^{10}$ The Spanish judge requesting Pinochet's extradition used the commission's report, while the national prosecuting authorities used the report in building their cases. ${ }^{11}$

\footnotetext{
${ }^{9}$ Decree Establishing the National Commission on Truth and Reconciliation, Supreme Decree No. 355, Chile (25 April 1990), reprinted in Neil J. Kritz (ed) Transitional Justice: How Emerging Democracies Reckon with Former Regimes (US Institute of Peace, vol 3, 1995) 102.

${ }^{10}$ See, for example, David Sugarman, 'The Pinochet Case: International Criminal Justice in Gothic Style' (2001) 2 Modern Law Review 933.

${ }^{11}$ By end of 2009779 former officials were charged with human rights crimes. Over 200 were convicted. Ibid.
} 


\section{Purpose}

A truth commission is a specific category for dealing with the past. Although meant to be independent, they can have an uneasy relationship with the law, in particular with criminal justice. There are several important questions about operations and management that determine a commission's competence and ultimately its effectiveness.

Many commissions have been created by presidential decree. The executive selects its members and sets the commission's mandate. The classic examples are that of Argentina and Chile. One argument for this way of establishing a commission is that it is less time consuming than relying on parliament to pass the relevant legislation. Ideally a commission should see public engagement and debate as part of the transitioning process and ownership. This latter element refers to individual or collective ownership over the process of revisiting the past; it is also about being involved in how this past (or predecessor state's history) should form part of the transitioning state's future. Examples of commissions set up through presidential actions are Argentina, Chad, Chile, Haiti, Sri Lanka and Uganda. With the exception of Argentina and Chile, where the civilian presidents took advantage of public support, the remainder of examples had little public debate on the commission's terms.

Other truth commissions are created through peace accord. One important example is Sierra Leone, discussed later in this chapter. Other examples include El Salvador, Guatemala, Liberia, the Democratic Republic of Congo, and Kenya. The El Salvadorian and Guatemalan commissions were administered by a UN Office and had members appointed by the UN, but did not operate as UN bodies per se. For example, in terms of identity, the Guatemalan commission was 'located in a no man's land between domestic and international law'. ${ }^{12}$ In most cases the terms of agreement were outlined in the national legislation.

Many commissions suffer from weak management. The head of the commission is an important post and one that should be headed by a respected and impartial individual. The

\footnotetext{
12 'Agreement on the Establishment of the Commission to Clarify Past Human Rights Violations and Acts of Violence that Have Caused the Guatemalan Population to Suffer' UN Doc A/48/954/S/1994/751, Annex II (23 June 1994).
} 
selection of the members of the commission is an underappreciated process. In many cases the selection of members has been done too hastily, and with little consultation. One of the best examples of a strong commission, based on their independence and knowledge, is in Ecuador, where a number of commissioners came from non-governmental organisations, in order to ensure that human rights activists worked with military representatives on the commissions. ${ }^{13}$ In Guatemala, members were selected from a list proposed by presidents of national universities. ${ }^{14}$

Commissions can be international, in both commission members and staff. In El Salvador, for example, the three commissioners and 25 staff members were all foreign. ${ }^{15}$ As noted above, the commission was set up under UN administration. The Commission tried to avoid hiring anyone with previous experience of working on El Salvadoran human rights issues, as such familiarity might have suggested a bias that could have affected the neutrality of the commission. Importantly, most El Salvadorans agreed that an El Salvadoran-staffed truth commission was not possible. They insisted that there were no El Salvadorans with the authority and political neutrality needed for the job. It was unlikely that a national commission would have been able to function otherwise. Witnesses would have perhaps been intimidated into giving testimony to fellow El Salvadorans because of their inability to trust the confidentiality of the process. This was evidenced in event that transpired after the creation of the follow-up commission looking into death squads. ${ }^{16}$ The commission recommended the removal of members of the armed forces from their positions as a result of human rights abuses. In addition, the confidential report recommended that over a hundred persons should be removed from the service. The members of the Commission received death threats, and two of the three left the country.

Other truth commissions have created a mixed model of national and international

\footnotetext{
${ }^{13}$ Priscilla B. Hayner, above n 1, 68-69.

${ }^{14}$ Ibid, 32-35.

${ }^{15}$ Ibid.

${ }^{16}$ For background on the conflict see Martha Doggett Death Foretold: The Jesuit Murders in El Salvador (Georgetown University Press, 1993) and Teresa Whitfield, Paying the Price: Ignacio Ellacuría and the Murdered Jesuits of El Salvador (Temple University Press, 1995).
} 
staff, while some countries exclude foreigners because the situation under investigation is too complex for outsiders, or also because the national pool from which to select staff is sufficient. Funds are relevant to the kind of commission that is set up. As she shall see below, where resources, in the form of individuals with the requisite knowledge as well as the physical space, are not available nationally, financial support from an international organisation is critical. It does not, however, result in effective results.

One of the most important questions about commission work is when should it start. A quick start has its advantages. The political momentum and popular support for such an initiative are highest at the point of transition, or initial beginning, when a new government takes power or an armed conflict has ended. An early start can also hold off for immediate reforms and other measures of accountability, providing the government with time to reflect, plan, and strengthen institutions integral to the transitional justice initiative. For example, one of the main contributions of the Chilean Commission was giving President Aylwin a year of grace. In certain contexts, this time is needed, in order to ensure measures are in place for the transitional justice mechanism to work. This allowed democratic institutions adequate space to work for one year before having to deal with past crimes and human rights violations. As noted by some scholars, a quickly created commission can be the 'centerpiece of a newfound peace' and one that 'often tests the boundaries of the new regime' and the willingness of authorities to cooperate with an independent investigation. ${ }^{17}$

It is vital to keep the tenure of the truth commission short. Very few are longer than two years. Extending the tenure runs the risk of losing momentum, focus, and both political and public attention. Outlining a work plan, collecting and organising the documents, receiving and processing testimony from thousands of victims, selecting representative cases completing investigations and finalising a report in a two-year period is undoubtedly a challenge. However it is useful if the report comes out when there is still the momentum of transition and reconciliation is a real prospect. This can occur when there are public calls for

\footnotetext{
${ }^{17}$ Priscilla B. Hayner, above n 1, 215.
} 
change and a public trust in this transitional justice measure. This way, the recommendations made by the commission have a better chance of being implemented. For example, the Commission of Inquiry for Uganda was created in 1986. But this Commission was given no time limit and, as a result, it concluded its work nine years later. ${ }^{18}$ By then the public had lost interest in the Commission's work.

Most truth commissions base their work on testimonies gathered from thousands of victims, witnesses and perpetrators. The findings can be standardised to reveal trends and patterns that would otherwise be unknown. If resulting in no fine, imprisonment, or other judicially imposed punishment, a truth commission's findings may negatively affect the persons and institutions named as responsible for abuses. To assign responsibility for killings or torture to one sector of the military or police might or should have implications for the future of the force and the culpability of the commanding officer. Reparations or other initiatives will be affected by the commission's conclusions about who the victims were, whether they were apolitical citizens caught up in the repression, or politicised supporters of armed rebels, or members of certain ethnic, regional or political groups. The standard of proof of past commissions has varied considerably. For example, the El Salvadoran Commission created a table setting out standards of proof for its individual findings. The thresholds identified levels of overwhelming evidence, or conclusive evidence to support its findings; substantial evidence, or very solid evidence to support the commission's findings; and sufficient evidence, or more evidence to support the commission's findings. ${ }^{19}$

Many truth commissions are established with or after a reparations programme. Even when quite substantial, many reparations programmes alone do not generally satisfy the victims' needs for a wider understanding of the events in question. Some individuals understandably might feel a lack of respect in the presumption that a cash payment might be sufficient in compensating for their pain. The manner in which the programme is carried out will help determine how it is received

\footnotetext{
${ }^{18}$ Ibid, 97-99.

${ }^{19}$ Ibid, 222.
} 
In Brazil, the government set up a reparations programme in 1995, a decade after the end of military rule. The Commission was to provide approximately $\$$ US100,000 to each family in some 135 cases of disappearances. (In the case of Velásquez Rodríguez ${ }^{20}$ the InterAmerican Court of Human Rights awarded a lump sum to the next of kin of the victim or to the family.) The Commission also had powers to conduct investigations into these cases, and this included exhumations. The result was an acknowledgement of the facts and 'rescuing historical truths and collective memory was deemed by many as the most relevant contributions of the process[es]' ${ }^{21}$ However, with full disclosure of the truth not forthcoming, owing to the lack of political will, there has been continued pressure to establish a follow-up commission to fulfil the task that many families are still yearning for - to establish where the remains of the disappeared can be found.

These two examples point to the complexities underpinning the design of a reparations commission - and again a universal design is simply not feasible for the same reasons as discussed in relation to truth commissions.

\section{Points of contention and controversy}

The founding terms of reference of the commission's mandate can range from a detailed exposition of competence to a short decree issued by the president. What is most important is that this is done in consultation with society, in particular with the victims and victims' families, and human rights organisations. However, as seen below, studies carried out on commissions have revealed that there is a lack of engagement with local practices, which might explain the later lack of commitment to the implementation and the recommendations made by the commission. This has also resulted in calls for a template that could be adopted by states that lack the necessary support structures in terms of personnel and resources. The point of contention that centres on ownership: commissions should be nationally established, unique to that place and reflect a process and involvement of the community. This is further

\footnotetext{
${ }^{20}$ Velásquez Rodríguez, decision from 29 July 1988, Inter-Am. Ct. HR (ser. C) No. 4, (1988).

${ }^{21}$ Priscilla B. Hayner, above n 1, 178.
} 
supported by the fact that commissions, for many places, represent the first inclusive process of policymaking in the transitioning phase towards democracy, between various segments of society. $^{22}$

One of the contentious questions concerns reconciliation itself and what it should look like. In her examination of whether reconciliation is beginning to be accepted, Hayner suggests three questions. The first question relates to the way that the past is dealt with in the public sphere. The key point is whether the people can talk about past conflicts and abuses not only with each other but with their former opponents. The second question concerns the basis of the relationships between former opponents - if they are based on the past or the present. The third question addresses the past or rather, which version of the past is being discussed and scrutinised. This is a paramount issue in this field of transitional justice. In the context of reconciliation, it means re-establishing relations and reconciling contradictory facts and stories. It is this third question that begs further research in this area. Is it possible to establish a 'single universe of comprehensibility'? ${ }^{23}$ Where conflict and violence have returned in cycles over generations, perceptions of the past can vary. This can make reconciliation difficult. Yet there is never just one truth. Each of us carries our own version of events and our own distinct memories. These may contradict each other. The process of disproving certain accounts might lead to an agreed settled account of history. There will be some facts that concern the specific crime frame that are basic enough that wide acceptance of their truth is necessary before real reconciliation can take place. ${ }^{24}$

From the perspective of victims, there are a few conditions that are favourable and others that are necessary before reconciliation can start to become accepted. First, there must be an end to the violence or the threat of violence. Secondly, there should be an officially

\footnotetext{
${ }^{22}$ Ibid, 178 .

${ }^{23}$ Ibid, 189. See Brasil: nunca Maís (Editora Vozes, 1985) and Torture in Brazil: A Shocking Report on the Pervasive Use of Torture by Brazilian Military Governments, 1964-1979, trans. Jaime Wright (University of Texas Press, 1998). Also Lawrence Weschler, A Miracle, A Universe: Settling Accounts with Torturers (Penguin, 1990).

${ }^{24}$ Goldstone, Richard J., 'Justice as a Tool for Peace-Making: Truth Commissions and International Criminal Tribunals' (1996) International Law and Politics 485.
} 
acknowledged recognition of the violent past. This should come from the perpetrators or be made by the political leaders. Thirdly, there needs to be projects that bring the community together, which enable relationships to be rebuilt. Fourthly, reconciliation should go beyond psychological and emotional processes. It also needs to address structural inequalities and material needs which, for example, the South Africa Truth Commission Report noted as necessary if there was to be any success and hope for national unity. These needs have not been adequately addressed in the period following the report. ${ }^{25}$ Finally, coming to terms with the past requires time, and expectations should be adjusted accordingly.

What about when a state decides to leave the past alone? Cambodia is known for its killing fields of the late 1970s, as is Spain and its mass graves. The Khmer Rouge government killed one to two million people, comprising up to one-fifth of the population. ${ }^{26}$ The manner in which Cambodians have chosen to remember has been less clear.

When the Khmer Rouge government collapsed in the 1980s, there was an initial interest in letting the world know about what happened. But the interest waned, and it was reported that Cambodians preferred to forget the past and many did not want to discuss it in public. Outside observers stated that among the community there was still some fear of talking about the past. Also, the Cambodian and Buddhist faith tradition tended not to confront conflict. However, the UN mission to Cambodia listed several reasons for this development, the most compelling being that many political, military, and financial elites could be implicated and, since many in the current government had at one time been affiliated with the Khmer Rouge, it was felt that accommodation was the preferred choice. As a result of this 'hushed' treatment of the past, the younger generation did not know the history and in fact doubted their elders' accounts of atrocities. Instead there was more focus on the crimes at an international level. In 1994 the US passed the Cambodian Genocide Act, which provided financial support for the Office of Cambodian Genocide Investigations at the US Department

\footnotetext{
${ }^{25}$ Romi Sigsworth and Nahla Valji, 'Continuities of Violence against Woman in South Africa: The Limitations of Transitional Justice', in Susanne Buckley-Zistel and Ruth Stanley (eds), Gender in Transitional Justice (Palgrave, 2011) 115-135.

${ }^{26}$ Priscilla B. Hayner, above n 1, 204.
} 
of State. ${ }^{27}$ This initiative led to the preservation of documentation that detailed the surveillance practices of the Khmer Rouge secret police and the structure of the regime.

Some of the Khmer Rouge surrendered in the late 1990s, and suddenly there was a desire to prosecute, but at the same time there was fear. People wanted to get on with their lives. A UN group of experts recommended a truth commission, but several doubted its potential success as many former Khmer Rouge members re-entered Cambodian society. In 2003, the government and the UN signed an agreement to create a special tribunal, the Extraordinary Chambers in the Courts of Cambodia. By 2006 it was in operation, with five suspects in custody with trials ready to go. While the need to know what happened seemed to be strong among Cambodian society, it was felt that the mixed tribunal would not provide the truth. In this case the international community has an important role to play, by providing the funding and staff to ensure key mechanisms are created and can operate. However, it cannot fulfil the needs of a society that is divided, i.e. when there is a fearful silence that has been suppressed or where interests are better served by silence or by portions of the truth coming out. $^{28}$

To meet the challenges of transitional justice, a society should investigate, establish and publicly disseminate the truth about past atrocities. The hard truth or forensic truth concerns information about the crime and what human rights were violated. There is also the emotional truth that refers to knowledge about the psychological and physical impact on the victims ${ }^{29}$ The rhetoric of political truth makes truth suspicious and exploited. Concrete political action to determine what happened is rare. So the way the past is used has a significant moral dimension. In other words, the political instrumentalisation of the past needs to be overcome..$^{30}$ It is this politicisation that results in public dissatisfaction and scepticism

\footnotetext{
${ }^{27}$ Ibid, 205.

${ }^{28}$ Priscilla B. Hayner notes a similar experience in Mozambique, above n 1, 297-204.

${ }^{29}$ David A. Crocker, 'Truth Commissions, Transitional Justice, and Civil Society' in Robert I. Rothberg and Dennis Thompson (eds), Truth v Justice: the Morality of Truth Commissions (University of Princeton Press, 2000) 99.

${ }^{30}$ For example, this objective motivates the Regional Committee for Establishing the Facts about War Crimes and Other Gross Violations of Human Rights on the Territory of the Former Yugoslavia at $\langle$ http://www.recom.link $\rangle$.
} 
about justice. The frustration is compounded when the report's findings do not result in any meaningful outcome.

\section{Key examples from Europe and Africa}

One of the most interesting examples of a commission is the Commission of Inquiry for the Assessment and Consequences of the Socialist Unity Party (SED) Dictatorship in Germany, 1992-1994, and the Commission of Inquiry on Overcoming the Consequences of the SED Dictatorship in the Process of German Unity, 1995-1998. These German examples show a commission that is involved in more of a symbolic mission than a fact-finding one. Although the two are separate, one led to the creation of the other. In 1992, the German parliament created a Commission to investigate and document the practices of the German Democratic Republic (GDR, or East Germany) government from 1949 to 1989. The Socialist Unity Party (SED) was the ruling party in the GDR. The structure of the Commission and its operation followed the country's guidelines for parliamentary commissions of inquiry. This meant that representation of political parties was equivalent to their representation in parliament as a whole. The SED successor, the Democratic Socialist Party, was represented on the commission with one member. Experts comprised 11 of the 27 members.

The East German regime is discussed differently in the literature, compared to its counterparts who were also the subject of commission inquiries. East German dictatorial rule physically repressed political opponents and dissidents, controlled freedom of movement and imposed organised surveillance on some of its political dissidents. The Commission's mandate went beyond the scope of human rights violations to a wider inquiry into state policy and practice, which included an investigation into the structure and practice of the SED regime, environmental degradation; political, mental and psychosocial repression; the role of ideology in education, literature, and daily life; Church-state relations, judicial independence, and relations between West and East Germany. ${ }^{31}$

\footnotetext{
${ }^{31}$ Priscilla B. Hayner, above n 1, 52-53.
} 
Public hearings accompanied the work of the Commission. It should be noted that the Commission had no subpoena power; many former government officials who were invited to give testimony declined for fear that these would be used against them in court. Importantly, the files from the East German secret police, the Staatssicherheit, or Stasi, were made available for individual review. The files permitted those who had been victims of Stasi informers to confront them directly. This occurred in private or before television cameras. The work of the Commission was shaped by this mandate and thus distinct from a commission such as South Africa's. Plus the German Commission preceded the South African one. 'The Commission demonstrates that a victim-centred examination and discussion of the past and its legacy is possible without a large-scale testimony collection' ${ }^{32}$ The first inquiry's report was released in 1995 and was over 15,000 pages. The second Commission released its report in 1998. Both arguably helped to frame the highly controversial question of how to memorialise this period.

The South African Truth and Reconciliation Commission is viewed as being the strongest truth commission. Its creation, in 1995, was a response to the apartheid regime, which had lasted 45 years. During this time the African National Congress (ANC) and other groups carried out armed resistance against the apartheid state. South Africa had endured massacres, killings, torture, lengthy imprisonment of activists, and severe economic and social discrimination against its majority non-white population.

After Nelson Mandela was elected president in 1994, serious discussions took place regarding the creation of a commission. At the heart of the debate was whether to grant amnesty to perpetrators of crimes, as insisted upon by the government and military. This amnesty would then be linked to the truth commission. Civil society had an important input into the creation of the Commission. In mid-1995 parliament passed the Promotion of National Unity and Reconciliation Act. Following a public nomination and selection process,

\footnotetext{
${ }^{32}$ Andrew H. Beattie, 'An Evolutionary Process: Contributions of the Bundestag Inquiries into East Germany to an Understanding of the Role of Truth Commissions' (2009) 3 International Journal of Transitional Justice 229.
} 
17 commissioners were appointed with Archbishop Desmond Tutu as chair. The work officially began in 1995, but started in 1996 after some delay in investigations.

The Commission was given the power to grant individualised amnesty, search premises and seize evidence, subpoena witnesses and run a witness protection programme. It had a staff of 300 and a budget of \$US18 million for the first two and a half years.

The Commission took testimony from 21,000 victims and witnesses, 2,000 of whom also appeared in public hearings. ${ }^{33}$ Media coverage was widespread, with a special television programme devoted to its work.

The Commission did not always make use of its strong powers. The powers of subpoena and search and seizure were applied only a few times. It was criticised by human rights organisations for not issuing a subpoena against the minister of human affairs. The Commission possibly was afraid of a violent reaction.

The greatest innovation of the Commission was its ability to grant individualised amnesty. ${ }^{34}$ The period covered by the amnesty was 1960 to April $1994.7,115$ applications for amnesty were received. If the crimes concerned gross violations of human rights, the applicant was required to appear at a public hearing to answer questions from the commission, from legal counsel representing the victims or victims' families and from the victims themselves. Amnesty was granted to those who fully confessed to their involvement in past crimes and showed them to be politically motivated. The Amnesty Committee considered a number of factors in determining whether the applications satisfied requirements. A significant factor was whether the crime was politically motivated. In fact, 4,500 applications were denied; most of them lacked a political objective. Neither an apology nor any sign of remorse was necessary to be granted amnesty, so to avoid inducing fake apologies. Of course, some perpetrators showed remorse and apologised.

There were several high profile trials that resulted in convictions. But when the trial of the former minister of defence (Magnua Malan) ended in acquittal it was felt that the threat

\footnotetext{
${ }^{33}$ Priscilla B. Hayner, above n 1, 28.

${ }^{34}$ Ibid, 29.
} 
of prosecution was not strong enough to persuade senior-level perpetrators to take advantage of the amnesty process. Several key amnesty decisions should be noted, such as the Stephen Biko case, where the admitted killers of the anti-apartheid activist were denied amnesty on the grounds that the perpetrators claimed that the death was accidental. Another controversial ruling was granting amnesty to 37 ANC leaders who applied jointly. Little details were provided. The commission granted the group collective amnesty, a decision that was later overturned by the Cape Town High Court on the grounds that they did not make the full disclosures as required by the amnesty provisions. The actions were gross human rights violations, but no further action has been taken, owing to lack of evidence, despite calls for prosecution by former South African police and generals. ${ }^{35}$

The Truth Commission did have its powers and decisions challenged in court. The decisions showed the dissatisfaction felt by some as regards the amnesty laws. Cassese recognised the difficult and sensitive nature of the project during the country's transitioning. ${ }^{36}$ In his analysis of the goals of international criminal justice, he draws our attention to the dilemma that amnesty laws present and refers us to the South African Constitutional Court case of Azanian Peoples Organization v President of the Republic of South Africa. ${ }^{37}$ In this ruling from 25 July 1995 the Act was upheld and, within that, its amnesty laws. The Court saw the Commission as a suitable solution for a country that is transitioning from one of terror towards democracy. Cassese makes an important point here regarding the choice to establish a commission, which might not be suitable for all transitioning states. He uses the example of former Yugoslavia, to indicate that perhaps a commission might not be best suited to a transition where, broadly speaking, a socialist democracy transitioning to several ethnically-based mini-states that remain antagonistic towards each other. In this vein

\footnotetext{
${ }^{35}$ Lovell Fernandez, 'Post-TRC Prosecutions in South Africa' in Gerhard Werle (ed), Justice in Transition: Prosecution and Amnesty in Germany and South Africa (BWV Berliner Wissenschafts Verlag,, 2006) 65. Also Priscilla B. Hayner, above n 1, 29-30.

${ }^{36}$ Antonio Cassese, 'Reflections on International Criminal Justice' (1998) 61 Modern Law Review, 1.

${ }^{37}$ Azanian Peoples Organization v President of the Republic of South Africa [1996] (4) SA 671.
} 
however, it is worth noting a civic initiative in 2005, namely the Regional Committee for Establishing the Facts about War Crimes and Other Gross Violations of Human Rights on the Territory of the Former Yugoslavia was established. Known as RECOM, it continues to be an unfinished political project. RECOM does not include truth in its name, but facts, in an effort to overcome political instrumentalisation and to counter the political memory of the past. ${ }^{38}$ RECOM endeavours to create a space for victims, by frequently referring to victims in its fact-finding. Facts can provide that necessary shift whereby victims become subjects with a name and story. Facts become meaningful that the victim's story is heard. ${ }^{39}$

Another factor that is discussed in Azanian Peoples concerns the difficulty of carrying out prosecutions - due to secrecy and the inability to collect the required proof to secure a prosecution. Moreover, in that case the Court asserted that amnesty, under the terms of the Act, was not awarded automatically and had to meet strict criteria. Sometimes amnesty and truth commissions are preferable to prosecutions, when the domestic system is too fragile to accommodate the trials against the threat of political instability. ${ }^{40}$

It should be noted that charges were brought against former president of South Africa P.W. Botha after he refused to appear before the Commission following a subpoena. The trial then became a forum for the commission to present its evidence against him, which included his knowledge or approval of a long pattern of state crimes. Botha was convicted and fined and given a one year suspended sentence. He successfully appealed to have his conviction overturned on a technicality. ${ }^{41}$

In another case involving former South African president F.W. de Klerk, the work of the Commission was temporarily blocked after de Klerk tried to stop the Commission from

\footnotetext{
${ }^{38}$ Regional Committee for Establishing the Facts about War Crimes and Other Gross Violations of Human Rights on the Territory of the Former Yugoslavia at $\langle$ http://www.recom.link〉 . Jacqueline Nießer, "A Truth and Reconciliation Commission that Dispenses with Truth? The Regional Committee for Establishing the Facts about War Crimes in the Yugoslav Wars', paper presented at the Association for Slavic, East European and Eurasian Studies Conference, Philadelphia, PA, USA, November 2015.

${ }^{39}$ Ibid.

${ }^{40}$ Antonio Cassese, 'Reflections on International Criminal Justice', above n 29, 4.

${ }^{41}$ Priscilla B. Hayner, above n 1, 30-31.
} 
naming him in the report. For its part, the ANC also attempted to block the publication of the Commission's report. The ANC was not satisfied with the conclusions drawn about its past actions. When the report was formally considered by the parliament, deputy president Thabo Mbeki, speaking in his capacity as president of the ANC, announced that the ANC had serious reservations about the Commission's report - noting that its findings seemed to delegitimise the ANC's struggle for liberation. In the end the government did not make any commitment to implement the Commission's recommendations because of these reservations.

The impact of the South African Truth and Reconciliation Commission on reconciliation has been the subject of ongoing debate. 'What remained clear to all, however, was that coming to terms with decades of abuses would take longer than a few years, and much more than speaking the truth' ${ }^{42}$

The Sierra Leone Truth and Reconciliation Commission and its work give rise to similar concerns, as well as other factors that identify other features of the work of a truth commission. An agreement for the Sierra Leone Truth and Reconciliation Commission was found in the Lomé peace accord that ended the country's civil war in July 1999. The agreement was signed into law through the Truth and Reconciliation Act in February 2000. After some delay owing to fighting between the government and rebel fighters, a public process was initiated to secure nominations for commissioners. According to the Act, the Commission was to undertake research, receive statements, and hold sessions with the aim of establishing 'an impartial historical record of violations and abuses of human rights and international humanitarian law related to the armed conflict in Sierra Leone', from the beginning of the conflict in 1991 to January 2002. The Act places special emphasis on victims of sexual abuse and on children who were either victims or perpetrators (child soldiers). While the Commission was meant to be a fully independent body, it was later decided that it would be administratively managed by the UN Office of the High Commissioner for Human Rights (OHCHR). While the OHCHR assisted with fundraising and administrative support,

\footnotetext{
${ }^{42}$ Priscilla B. Hayner, above n 1, 31-32.
} 
some questions were raised concerning the Commission's independence in making operational decisions. The operating budget was less than \$US5 million; limited finds and a strict timeline reduced its scope, the taking of statements, and public hearings.

It should be noted that there was strong support for the Commission's work from former combatants. Over 10 per cent of the statements came from perpetrators. The more the Commission's work became publicised, the more support it garnered. In fact, public hearings were held across the country, accompanied by 'reconciliation ceremonies', where victims and perpetrators got together, and went through a ritual ceremony to return and be reaccepted to the community. Eventually the work of the Commission overlapped with that of the Special Court for Sierra Leone, created in 2002 after an agreement between the government and the UN. The Court's mandate was to prosecute those 'bearing the greatest responsibility' for crimes after November 1996.

The Commission published a four-volume report that was concluded in 2004. It included a video summary and a child-friendly version. In this way the country hoped to escape the dilemma that was common to other commissions - that of the government failing to act on the recommendations presented in the final report. The country set out to implement the recommendations. A follow-up committee was created, with national and international members, which would submit quarterly reports and supervise the plan. But these mechanisms were never made operational.

There was little commitment shown by the government. Despite slow progress and marginal success in the initiatives eventually put in place for women and children, there is hope in that the experience has led to important studies about the shortcomings of commissions. One of the most valuable is that commissions run counter to local understandings about healing and reconciliation, suggesting that such operations might pay attention to local practices to overcome obstacles to healing. ${ }^{43}$

Studies have shown that truth telling may affect views on group security over a long-

\footnotetext{
${ }^{43}$ Rosalind Shaw, 'Rethinking Truth and Reconciliation Commissions: Lessons from Sierra Leone' United States Institute for Peace, Special Report 130 (February 2005).
} 
term period in post-conflict societies. ${ }^{44}$ This is especially so in societies divided along cultural lines, where truth telling might exert some peace-promoting influence. Of the documented truth commissions, most are in Africa, followed by Asia, the Americas and Europe. ${ }^{45}$ These recent studies show that there so much interest in creating new truth commissions because of their impact on transforming public discourses on memory, truth, justice and reconciliation. These new avenues are created even when the commissions seemingly produce modest changes owing to political constraints. ${ }^{46}$ It is true that the academic scholarship is largely based on the better-known commissions. Greater attention from the international human rights advocacy community tends to focus on criminal justice. The dominance of this legal perspective may be missing the complexities and importance of parallel, non-judicial initiatives. Truth commissions directly impact on thousands of victims, and on the possibility of criminal justice, reforms, reparations, reconciliation, and community relations. The interdisciplinary asset of the field of transitional justice should be used to carry out deeper legal analysis of truth commissions. For example what is the link of TRC's to courts? Or, what is the impact on trauma and healing across time and regions? A recent study on the Liberian Truth and Reconciliation Commission reveals some important factors that might help explain what underpins the success of a truth commission.

The Liberian Commission was created in 2005 further to the 2003 Accra Comprehensive Peace Agreement that was concluded to address the country's legacy of human rights violations in the context of its civil wars in the period 1979 to 2003 . According to Ezekiel Pajibo, 'Warring parties [in Liberia] agreed to the TRC concept because they wanted to prevent the establishment of a war crimes tribunal' ${ }^{47}$ One factor that might have influenced this position was the arrest in 2003 of Charles Taylor on charges of war crimes and

\footnotetext{
${ }^{44}$ David Mendeloff, 'Truth-Seeking, Truth-Telling, and Post-Conflict Building: Curb the Enthusiasm? (2004) 6 International Studies Review 355.

${ }^{45}$ Tricia D. Olsen, Leigh A. Payne and Andrew G. Reiter, Transitional Justice in Balance: Comparing Processes (United States Institute of Peace, 2010).

${ }^{46}$ Onur Bakiner, Truth Commissions, Memory, Power, and Legitimacy (University of Pennsylvania Press, 2016).

${ }^{47}$ Ezekiel Pajibo, 'Civil Society and Transitional Justice in Liberia: a Practitioner's Reflection from the Field' (2007) 1 International Journal of Transitional Justice 287.
} 
crimes against humanity in Sierra Leone by the Special Court for Sierra Leone.

The Liberian Commission investigated violations that occurred between January 1979 and October 2003, marking the period of the final year of the Americo-Liberian rule and the inauguration of the National Transitional Government for Liberia. ${ }^{48}$ The composition of the Commission included nine commissioners: three from civil society, two from political parties, one from the UN, and one from the Economic Community of Western African Societies. Out of nine four women were in the Commission for gender balance. Gender is often neglected on the transitional justice process and scholars have argued that transitional justice mechanisms require a change in procedures (such as memberships on truth commissions) to address this inequality. ${ }^{49}$ Due to the absence of adequate funding and resources the commission did not have the expertise to make a solid legal evaluation of the cases. The final report of the Commission was made in 2008, when it was presented to the Liberian legislature. It contains four volumes. One of the most unique contributions was the Commission's inclusion of the diaspora community throughout the report. This is the first of its kind. The involvement of the community was paramount, as thousands fled the conflict creating large communities in West Africa, Europe, and the United States. Their contribution included outreach, statement taking, report writing and being present at the public hearings. Another unique contribution of the Commission was the Palava Hut Forum as a complementary tool for justice and national reconciliation. This process recommended that the process be based on traditional dispute resolution mechanisms. The Palava Hut process was used in pre-settler Liberia. It was convened by elders to settle community matters. Traditionally a confession was sought for the wrongful deed, followed by an apology for the wrong committed, forgiveness from the victim, and cleansing rituals and restitution. This sanction was limited to lesser crimes only, and not available for international crimes. Significantly, the informal justice system had more support and trust than the formal court

\footnotetext{
${ }^{48}$ Carla de Ycaza, 'A Search for Truth: A Critical Analysis of the Liberian Truth and Reconciliation Commission' (2013) 14 Human Rights Review 189.

${ }^{49}$ Nesiah, Vasuki, et al, 'Truth Commissions and Gender: Principles, Policies and Procedures', International Center for Transitional Justice (July 2006).
} 
system. The Liberian Commission Report also included an investigation of economic crimes, as the exploitation of resources was one of the primary causes underpinning the conflict. The Report sets out an extensive definition of the crimes, as well as a list of individuals and corporations that the commission holds responsible for economic crimes.

The Liberian Commission's work has made an invaluable contribution to the mapping of human rights abuses. As part of its mandate it conducted the National Conflict Mapping Survey that identified the emerging conflict issues that had the potential to undermine the peace process and that would influence the 'conflict sensitive' policy recommendations it would make. Despite the difficulties, the Liberian Commission succeeded in making an original and important contribution to our understanding of transitional justice and its many mechanisms. It succeeds in advancing our critique about the role of the law in the area, and acknowledging the vital role that non-legal actors and other forms of knowledge have to play in the area of reconciliation..$^{50}$

\section{A short summary}

This chapter has considered the definition of a truth and reconciliation commission and that its key components of truth, reconciliation and commission that carry broad plethora of responsibilities and expectations.

The founding terms of reference of the commission's mandate can range from a detailed exposition of competence to a short decree issued by the president. What is most important is that this is done in consultation with society, in particular the victims and victims' families, human rights organisations, and key independent actors. However, as seen above, studies carried out on commissions have revealed that there is a lack of engagement with local practices, which might explain the later lack of commitment to the implementation of the recommendations made by the commission. Also, this has resulted in calls for a

\footnotetext{
${ }^{50}$ Kieran McEvoy, 'Beyond Legalism: Towards a Thicker Understanding of Transitional Justice' (2007) 34 Journal of Law and Society 411.
} 
template that could be adopted by states that lack the support structures. Another controversial and highly significant point arises in relation to ownership: commissions should be nationally established, unique to that place and reflect a process, which involves the community. Commissions, for many places, are the first inclusive process of policymaking in the transitioning phase towards democracy, between various segments of society. This begs the question of whether a general standard model is even possible.

Certainly more studies need to be carried out with respect to the commissions that have been created, with a view to answering the question of why is there so much interest in creating new truth commissions. Academic scholarship is largely based on the better-known commissions. On the part of the international human rights advocacy community, criminal justice predominates. The dominance of this legal perspective lacks an appreciation of the complexities and importance of parallel, non-judicial initiatives. Truth commissions directly impact on thousands of victims, and on the possibility of criminal justice, reforms, reparations, reconciliation, and community relations. The interdisciplinary asset of the field of transitional justice should be used to carry out deeper legal analysis of truth commissions. For example what is the link to courts? Or, what is the impact on trauma and healing across time and regions? The contemporary examples of commissions, such as Sierra Leone and Liberia, bring us close to such an understanding.

\section{Discussion questions}

Should a truth commission be national, international or a mix? What considerations are important to bear in mind?

When should the work of the commission begin?

How long should it carry on?

Should there be a general, universal template to assist in the setting up of a commission?

What should be done with the commission's findings (i.e. prosecution)?

What is the role of the international community in the establishment of the TRCs? 


\section{Suggested further readings}

Blair, James T., 'From the Numbers Who Dies to Those Who Survived: Victim Participation in the Extraordinary Chambers in the Courts of Cambodia' (2009) 31 University of Hawaii Law Review 507

Braithwaite, John, Valerie Braithwaite, Michael Cookson, Leah Dunn, Anomie and Violence: Non-truth and Reconciliation in Indonesian Peacebuilding (Australian National University E Press, 2010)

Collins, Cath, 'Chile 2014 ¿Una Nueva Medida de lo Posible? Verdad, Justicia, Memoria y Reparaciones Pos Dictadura' Chile 2014 - New Possibilities for post-Dictatorship Truth, Justice, Memory and Reparations', Transitional Justice Research Institute Paper No. 15-07

Simić, Olivera and Peter D. Rush (eds), The Arts of Transitional Justice (Springer, 2012)

Soares, Patrícia Pinto 'Positive Complementarity: Fine-Tuning the Transitional Justice Discourse? The Cases of the Democratic Republic of Congo, Uganda and Kenya' in A. Fijalkowski and R. Grosescu (eds), Post-Dictatorial and Post-Conflict Transitional Criminal Justice (Intersentia, 2015) 187

Sullo, Pietro,'Punishing Mass Atrocities: Penological Developments in the Aftermath of the Rwandan Genocide' in A. Fijalkowski and R. Grosescu (eds), Post-Dictatorial and PostConflict Transitional Criminal Justice (Intersentia, 2015) 209

Stovel, Laura, Long Road Home: Building Reconciliation in Sierra Leone (Intersentia, 2010)

\section{References}

\section{Articles/Books/Reports}

Brasil: nunca Maís (Editora Vozes, 1985)

Cassese, Antonio, 'Reflections on International Criminal Justice' Modern Law Review (1998)

$61(1998) 1$

Bakiner, Onur, Truth Commissions, Memory, Power, and Legitimacy (University of Pennsylvania Press, 2016) 
Bakiner, Onur, 'Truth Commission Impact: an Assessment of How Commissions Influence Politics and Society' (2014) 8 International Journal of Transitional Justice 6

Beattie, Andrew H., 'An Evolutionary Process: Contributions of the Bundestag Inquiries into East Germany to an Understanding of the Role of Truth Commissions' (2009) 3 International Journal of Transitional Justice 229

Crenzel, Emilio, 'Argentina's National Commission on the Disappearance of Persons:

Contributions to Transitional Justice' (2008) 2 International Journal of Transitional Justice 173

Crocker, David A., 'Truth Commissions, Transitional Justice, and Civil Society' in Robert I. Rothberg and Dennis Thompson (eds), Truth v Justice: the Morality of Truth Commissions (University of Princeton Press, 2000) 99

Doggett, Martha, Death Foretold: The Jesuit Murders in El Salvador (Georgetown University Press, 1993)

Fernandez, Lovell, 'Post-TRC Prosecutions in South Africa' in Gerhard Werle (ed), Justice in Transition: Prosecution and Amnesty in Germany and South Africa (BWV Berliner

Wissenschafts Verlag,, 2006) 65

Ferrara, Anita, Assessing the Long Term Impact of Truth Commissions: the Chilean Truth and Reconciliation Commission in Historical Perspective (Routledge, 2014)

Goldstone, Richard J., 'Justice as a Tool for Peace-Making: Truth Commissions and International Criminal Tribunals' (1996) International Law and Politics 485

McEvoy, Kieran, 'Beyond Legalism: Towards a Thicker Understanding of Transitional Justice (2007) 34 Journal of Law and Society 411

Mendeloff, David, 'Truth-Seeking, Truth-Telling, and Post-Conflict Building: Curb the Enthusiasm?' (2004) 6 International Studies Review 355

Nesiah, Vasuki, et al, 'Truth Commissions and Gender: Principles, Policies and Procedures', International Center for Transitional Justice (July 2006)

Nießer, Jacqueline, 'A Truth and Reconciliation Commission that Dispenses with Truth? The Regional Committee for Establishing the Facts about War Crimes in the Yugoslav Wars', 
paper presented at the Association for Slavic, East European and Eurasian Studies

Conference, Philadelphia, PA, USA, November 2015

Orentlicher, Diane, 'Settling Accounts: the Duty to Prosecute Human Rights Violations of a Prior Regime' (1991) 100 Yale Law Review 2537

Shaw, Rosalind, 'Rethinking Truth and Reconciliation Commissions: Lessons from Sierra Leone' United States Institute for Peace, Special Report 130 (February 2005)

Sigsworth, Romi and Nahla Valji, 'Continuities of Violence against Woman in South Africa:

The Limitations of Transitional Justice' in Susanne Buckley-Zistel and Ruth Stanley (eds),

Gender in Transitional Justice (Palgrave, 2011) 115

Sugarman, David, 'The Pinochet Case: International Criminal Justice in Gothic Style' (2001)

64 Modern Law Review 933

Torture in Brazil: A Shocking Report on the Pervasive Use of Torture by Brazilian Military Governments, 1964-1979, trans. Jaime Wright (University of Texas Press, 1998)

Ycaza, Carla de, 'A Search for Truth: A Critical Analysis of the Liberian Truth and Reconciliation Commission' (2013) 14 Human Rights Review 189

Weschler, Lawrence, A Miracle, A Universe: Settling Accounts with Torturers (Penguin, 1990)

Whitfield, Teresa, Paying the Price: Ignacio Ellacuría and the Murdered Jesuits of El Salvador (Temple University Press, 1995)

\section{Cases}

Azanian Peoples Organization v President of the Republic of South Africa [1996] (4) SA 671

Velásquez Rodríguez, decision from 29 July 1988, Inter-Am. Ct. HR (ser. C) No. 4, (1988)

\section{Legislation}

Decree Establishing the National Commission on Truth and Reconciliation, Supreme Decree No. 355, Chile (25 April 1990) reprinted in Neil J. Kritz (ed), Transitional Justice: How

Emerging Democracie Reckon with Former Regimes (US Institute of Peace, vol. 3, 1995) 102 


\section{Other}

Agreement on the Establishment of the Commission to Clarify Past Human Rights Violations and Acts of Violence that Have Caused the Guatemalan Population to Suffer', UN Doc A/48/954/S/1994/751, Annex II (23 June 1994)

Regional Committee for Establishing the Facts about War Crimes and Other Gross Violations of Human Rights on the Territory of the Former Yugoslavia, at <http://www.recom.link $>$

\section{Suggested documentary/films}

A Long Night's Journey into Day (dir. Deborah Hoffman and Francis Reid, 2000)

Beasts of No Nation (dir. Cary Fukunaga, 2015)

Cry Freetown (dir. Sorious Samura, 2000)

Life does not lose its value: Father Berton and the former soldiers of Sierra Leone (dir. Wilma Massucco, 2012)

\section{Plays}

Eclipsed (written by Danai Gurira, opened 2015) 